УДК: 330.3:616-036.21(497.11)

DOI: https://doi.org/10.18485/fb_covid19.2020.ch6

\title{
ЕКОНОМСКЕ ПОСЛЕДИЦЕ КОВИДА 19 И МЕРЕ ПОДРШКЕ ПРИВРЕДИ РЕПУБЛИКЕ СРБИЈЕ ${ }^{1}$
}

\author{
др Сања Јелисавац Трошић², \\ др Ана Јовић-Лазић ${ }^{3}$
}

\begin{abstract}
Апстракт: Више од 10 година након светске финансијске кризе дошла је криза изазвана вирусом ковид 19. Нова криза доноси још увек несагледиве економске последице које прете да буду и разорније. У раду ће поред уводних и закључних разматрања бити обрађене још четири целине. Прва целина чини сагледавање економских последица вируса ковид 19 на светску привреду, друга анализира економске последице вируса ковид 19 на привреду Републике Србије. Трећи део рада обухвата економске мере подршке Владе Републике Србије намењене одржању и опоравку привреде, док је четврти део рада посвећен оценама економских мера и прогнозама трендова у привреди Србије. Закључна разматрања ће обухватити поуке које смо могли извући из досадашњег тока кризе проузроковане ковидом 19, оцену ефикасности мера Владе Републике Србије за очување привредног система, као и очекивања будућих економских кретања.
\end{abstract}

Кључне речи: економија, економске последице, привреда, ковид 19, Република Србија

\section{УВОД}

У Републици Србији, као и у многим другим земљама у свету, упоредо са борбом против пандемије ковида 19 траје непрекидна борба за очување економског система земље. С обзиром на то да се још увек не зна, нити се може са сигурношћу претпоставити, колико ће трајати пандемија и борба са вирусом, као ни које ће се

\footnotetext{
1 Рад је настао у оквиру научноистраживачког пројекта „Србија и изазови у међународним односима 2020. године“, који финансира Министарство просвете, науке и технолошког развоја Републике Србије, а реализује Институт за међународну политику и привреду током 2020. године.

2 Институт за међународну политику и привреду, Београд, e-mail: sanja@diplomacy.bg.ac.rs.

3 Институт за међународну политику и привреду, Београд, e-mail: anajovic@diplomacy.bg.ac.rs.
} 
још мере морати предузимати, како у погледу очувања здравља, тако и у погледу очувања економског система - веома је незахвално прогнозирати последице по привреду земље. Прогноза и процена која би се у овом моменту могла са одређеном дозом сигурности исказати јесте да ће пандемија негативно утицати на српску економију, мада ће утицај највероватније бити блажи него у осталим европским земљама. Може се већ предвидети да ће Република Србија 2020. године ући у рецесију, односно искусиће пад економских активности, као и већина земаља света. Моменат изласка из рецесије и привредни опоравак ће се највероватније поклопити са моментом укидања највећег броја ограничења кретања и привређивања.

За разлику од финансијске кризе из 2008. године, ове 2020. године свет је суочен са неочекиваним околностима које се развијају изван економских токова. Према томе, од борбе и победе здравственог система зависи и борба и напредак свих других људских активности. Пошто привреда не може да стоји и чека да се нађу решења за пандемију, а свесни шокова које трпе разне привредне гране, велики број земаља је предузео и мере за очување привредног система. Република Србија прогласила је 15. марта 2020. ванредно стање у земљи, које је трајало до његовог обустављања 6. маја 2020. године. Уследиле су и економске мере Владе Републике Србије за подршку привреди.

Још увек постоји велика и здравствена и привредна неизвесност да би се прецизније могла прогнозирати економска кретања. Опоравак различитих држава, односно њихових привреда у свету ће се сигурно одвијати различитим темпом, у зависности од много фактора, међу којима су најважнији: снага и развијеност привреде, трајање ковида 19, трајање епидемиолошких мера против вируса, од тога колики удео у стварању БДП имају најугроженији привредни сектори и друго. Осим преливања вируса који не познаје државне границе, тржишта у свету су у већој или мањој мери међусобно повезана, тако да ће се шокови или таласи кризе смењивати са различитим амплитудама. Република Србија, посматрано са економског становишта, путем трговинских и инвестиционих канала највише је повезана са ЕУ, тако да ће и њен опоравак у великој мери зависити од привредног опоравка земаља чланица. Тренутне пројекције међународних организација показују да ће се Србија опоравити у 2021. години након рецесије у 2020. години. У поређењу са другим државама региона, према тренутним пројекцијама, можемо видети да ће негативни утицај на српску економију бити нешто слабији него у осталим европским земљама.

\section{ЕКОНОМСКЕ ПОСЛЕДИЦЕ КОВИДА 19 У СВЕТУ}

Када се појави рецесија, њени најчешћи узроци су спољни шокови и/или неадекватна монетарна политика. Пандемија ковида 19 спољни је шок, који је веома брзо гурнуо цео свет у рецесију. Није, нити ће свака земља бити исто погођена, али ће се криза сигурно преливати и ширити у више таласа, јер ће се у савременом глобализованом свету преливати као систем спојених судова. Давно је прошло време када криза у једном делу света није имала никакве утицаје на 
привређивање земаља у другим деловима света. Доба глобализације, међуповезаности привреда света, пословног повезивања међу предузећима, олакшаног кретања радне снаге и други фактори либерализације, омогућили су са једне стране раст продуктивности, производње и трговине, али са друге стране лакше и брже ширење свих екстерних шокова. Посебно осетљиве су мале и отворене привреде, у које спада и Србија. Осим тога, глобална повезаност тржишта за последицу ће имати дуже трајање кризе и спорији опоравак земаља. Beћ почетне процене говоре у прилог томе да ће ово бити рецесија светских размера, далеко већа него што је то била финансијска криза 2008. године.

Међународни монетарни фонд (ММФ) је у априлу издао извештај „Светска економска прогноза: Велико затварање“, у којем се предвиђа да ће светска привреда снажно пасти за 3\% у 2020. години, што је дубљи пад него током финансијске кризе 2008-09. године. Опоравак је у априлу био прогнозиран остваривањем раста светске привреде од 5,8\% у 2021. години. ${ }^{4}$ С обзиром на то да опасност од вируса још увек траје, вероватно је да ће овај пад бити и израженији. Велико је питање да ли ће се светска привреда почети опорављати током ове године или ће се рецесија проширити и на следећу годину. У новијем извештају „Светска економска прогноза: Криза као ниједна друга, несигурни опоравак“ предвиђање глобалног пада је 4,9\% у 2020. години, што је већ за 1,9 процентних поена испод претходне прогнозе из априла.

Пандемија ковида 19 имала је у првој половини 2020. године негативнији утицај на привредну активност него што се у почетку предвиђало, а опоравак се сада очекује поступније него што се раније веровало. У најновијем извештају из јуна глобални раст у 2021. години се прогнозира на 5,4\%. Осим тога, у међувремену су се знатно продубили буџетски дефицити, јер су земље до сада потрошиле скоро 11 билиона долара за сузбијање негативних последица вируса по економију. Процењује се да је 300 милиона запослених остало без посла. ${ }^{5}$ Непосредно пре почетка пандемије у извештају ММФ из јануара 2020. „Светска економска прогноза: Привремена стабилизација, спор опоравак?“ прогнозе су биле сасвим другачије. У том извештају предвиђао се глобални раст са процењених 2,9\% у 2019. години на 3,3\% у 2020. години и 3,4\% за 2021. годину. На финансијским тржиштима је присутна велика неизвесност и нестабилност. Иако је у једном моменту дошло до пораста оптимизма и очекивања да ће ускоро започети економски опоравак, раст броја заражених и константни страх од другог таласа пандемије оставља утисак да ће економски опоравак ипак бити дуг и неизвестан. А сам почетак економског опоравка неће зависити од економских, већ од фактора који нису економски (слабљење вируса, проналазак вакцине, укидање физичког дистанцирања и др.).

\footnotetext{
${ }^{4}$ IMF, World Economic Outlook, April 2020: The Great Lockdown, April 6, 2020.

${ }^{5}$ IMF, World Economic Outlook Update, June 2020: A Crisis Like No Other, An Uncertain Recovery, June 24, 2020.
} 
Економске активности свуда у свету су погођене и драстичним падом тражње, односно потрошње из више разлога, али пре свега због тога што су многи грађани остали без посла и због неизвесне будућности мање купују него раније. У ранијим економским кризама потрошња је била мање погођена него инвестиције; међутим, пандемија ковида 19 изазвала је велику неизвесност, неизвесност у дужини трајања пандемије, као и неизвесност у дубини и ширини економских последица, па многи посежу за тзв. штедњом из предострожности, јер не знају шта доноси будућност. Према наводима ММФ-а, светској привреди ће бити потребно две године да се врати на ниво са краја 2019. године. „Пандемија ковида 19 довела је до велике блокаде, односно затварања економија, што је помогло у обуздавању вируса и спасавању живота, али је изазвало највећу рецесију од Велике депресије“, наводи економска саветница и директор Одељења за истраживање ММФ-а Гита Гопинат (Gopinath). Она је истакла да предвиђени пад светске економије у 2020. износи половину у односу на 1930-те, када је привреда била у минусу 10 одсто. Истовремено, у време глобалне финансијске кризе почетком 2009. године економски пад је износио 0,1 одсто. ${ }^{6}$

Размере кризе у свету изазване ширењем вируса ковида 19 доводе до закључка да ће и убудуће бити потребна додатна подршка монетарне политике домаћој економији свих земаља света погођених пандемијом ради ублажавања негативних ефеката кризе и подстицања привредног раста у наредном периоду.

\section{ЕКОНОМСКЕ ПОСЛЕДИЦЕ КОВИДА 19 У СРБИЈИ}

\section{Бруто домаћи производ}

Пре пандемије српска привреда је имала реални раст бруто домаћег производа (БДП) од 4,2\% (у 2019. години), јавни дуг је био 52,1\% БДП-а, и стопу незапослености од 10,5\%. Пре ковида 19 Влада Србије је пројектовала 4,0\% раста за 2020. годину. Краткорочни показатељи говоре да је раст остао снажан у првом кварталу 2020. године, али очекивани позитивни резултати су изненада заустављени због избијања пандемије ковида 19. Избијање пандемије довело је до нижег раста српске привреде него што се раније очекивало. У првом кварталу 2020. године десезонирана серија података показује пад БДП од 0,6\% у односу на претходни квартал. Са друге стране, у истом периоду реални раст бруто додате вредности забележен је у сектору грађевинарства 19,6\%, у сектору информисања и комуникација $11,8 \%$, у сектору државне управе и обавезног социјалног осигурања, образовања и здравствене и социјалне заштите $11,8 \%$ и у сектору индустрије и снабдевања водом и управљања отпадним водама 4,5\%. Посматрано

\footnotetext{
6 Драган Штављанин „ММФ: Економска ситуација гора него што се предвиђало“, Радио Слободна Европа, 25. јун 2020,

https://www.slobodnaevropa.org/a/mmf-ekonomska-situacija-gora-odpredvidjanja/30690214.html, 15/08/2020.
} 
по агрегатима употребе бруто домаћег производа, у првом кварталу 2020. године, у односу на исти период претходне године, реални раст забележен је код свих агрегата: издаци за финалну потрошњу домаћинстава $3,2 \%$, издаци за финалну потрошњу непрофитних институција које пружају услуге домаћинствима $3,4 \%$, издаци за финалну потрошњу државе 12,0\%, бруто инвестиције у основна средства $10,7 \%$, извоз робе и услуга $3,1 \%$ и увоз робе и услуга $8,3 \% .^{7}$

Графикон 1: Стопа раста БДП у Србији пре доласка ковида $19^{8}$

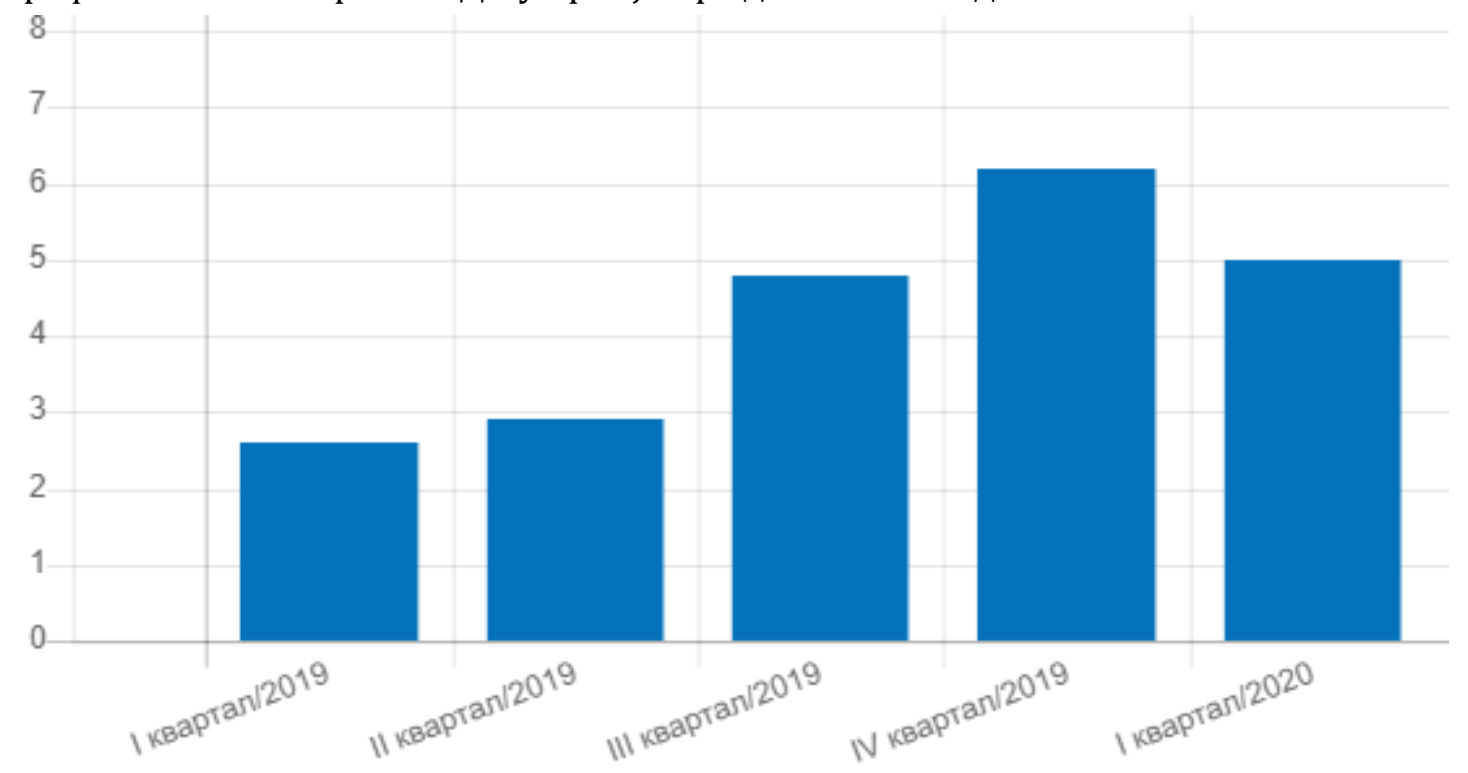

Према економској пројекцији ММФ-а, у 2020. години Србију очекује пад БДП-а од $3 \%$, а потом 2021. године раст од 7,5\%. ${ }^{9}$ Одређену дозу оптимизма нуде прогнозе ММФ-а, које су у јуну додатно смањили пројекције раста на глобалном нивоу за велики број земаља, за Србију су задржали априлску пројекцију због, правовременог и свеобухватног одговора на кризу. ${ }^{10}$ ММФ је приметио да економски план Републике Србије наставља да даје јаке макроекономске резултате и предложио редефинисање постојећих фискалних правила у циљу обезбеђивања очувања фискалне одрживости, као и приватизацију Комерцијалне

7 „Квартални бруто домаћи производ у Републици Србији, први квартал 2020. године“, Републички завод за статистику, 1. јун 2020, https://www.stat.gov.rs/sr-

latn/vesti/20200601-kvartalni-bruto-domaci-proizvod-u-republici-srbiji-prvi-kvartal-2020godine/, 16/08/2020.

8 Републички завод за статистику, https://www.stat.gov.rs/, 16/08/2020.

9 IMF, World Economic Outlook (April 2020).

10 „Србија једина земља којој ММФ није смањио прогнозу раста“, ТВ Mocm, 02. Јул 2020, https://www.tvmost.info/post/srbija-jedina-zemlja-kojoj-mmf-nije-smanjio-prognozurasta, 16/08/2020. 
банке и ХИП Петрохемије. ${ }^{11}$ Према плану договореном са ММФ-ом, јавни дуг Србије не би требало да пређе 60\% БДП-а, са 52,4\% на крају 2019. године. Када је реч о периоду након почетка пандемије, према проценама ММФ-а, пројектован је пад бруто домаћег производа за 2020. годину од 3\%, што је најмањи пад у поређењу са суседима у региону. Наиме, поред земаља које у значајној мери зависе од туризма, као што су Црна Гора и Хрватска, а чији пројектовани бруто домаћи производ за 2020. према процени ММФ-а из априла износи $-9.0 \%$; ту су Северна Македонија, чији пројектовани бруто национални производ износи -4\%, Босна и Херцеговина и Албанија -5\%. Процене које долазе од ММФ-а за Србију су благо боље, имајући у виду процене у региону, али и шире.

Према најновијем извештају Светске банке из јуна 2020. дају се нешто другачије прогнозе у односу на поменуте прогнозе ММФ-а. Наиме, за Србију је прогнозирано да ће имати мањи пад, и то од 2,5\% (Северна Македонија 2,1\%, Црна Гора 5,6\%, Албанија 5\%, Босна и Херцеговина 3,2\%, Хрватска 9,3\%). Светска банка процењује да ће српска привреда 2020. године ући у рецесију, вођена мањом туристичком и транспортном активношћу, нижим дознакама, успоравањем извоза и нижим директним страним инвестицијама и инвестицијама у целини. „Средњорочно (2021-2023) раст ће се вратити на своју претходну путању. Овај средњорочни поглед пресудно зависи од међународног развоја (укључујући утицај ковида 19), темпа структурних реформи и политичког развоја“.12

С обзиром на процес приступања ЕУ, као и на многобројне привредне, инвестиционе и трговинске везе које Република Србија има са ЕУ, развој привредних кретања у нашој држави умногоме зависи и од прогноза привредног опоравка саме ЕУ. Према Европској економској прогнози из пролећа 2020. године, негативни утицај пандемије ковида 19 и мера уведених у циљу очувања здравља на економију заједнице, довешће до смањења БДП-а у ЕУ за око 4\% у 2020. години. Према прогнозама Европске комисије јавни дефицит и дуг ће се снажно повећати с обзиром на мере за ублажавање кризе. Предвиђа се да ће јавни дуг порасти изнад 60 процената БДП-а у 2020. години, што ће се одразити и на висок дефицит и пад БДП-а, а затим ће уследити постепени пад 2021. године у складу са економским опоравком и смањењем дефицита. Снажан опоравак БДП-а за 6\% се очекује у 2021. години. Прогнозира се да ће оба, и пад и опоравак у ЕУ, бити углавном вођени приватном потрошњом и инвестицијама. За сада се не очекује да

\footnotetext{
11 "IMF Staff Completes a Virtual Review Mission to Serbia July 3, 2020", The International Monetary Fund, 03. Jul 2020, https://www.imf.org/en/News/Articles/2020/07/02/pr20253serbia-imf-staff-completes-a-virtual-review-mission, 17/08/2020.

12 "The World Bank in Serbia", The Word Bank, https://www.worldbank.org/en/country/serbia/overview, 17/08/2020.
} 
ће свеукупно ограничено трајање мера изолације трајно утицати на производне капацитете и дугорочну путању раста у привредама ЕУ.13

Графикон 2: Реални раст БДП-а, процентни поени, процена Светске банке ${ }^{14}$

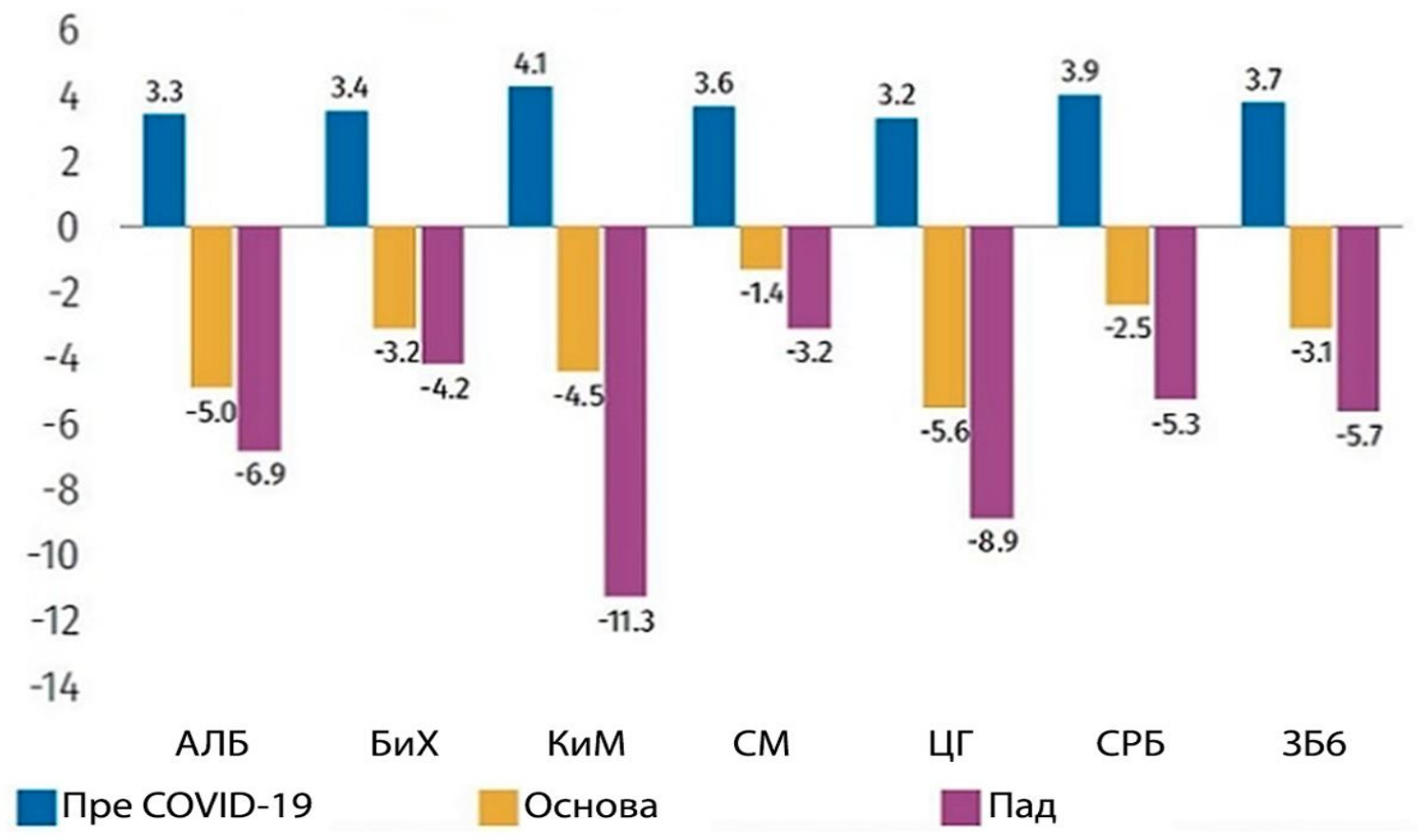

Учешће пољопривреде у привреди Републике Србије је око 7,5\%, више него двоструко у односу на земље централне и источне Европе чланице ЕУ, где је просек 3,3\% и пет пута веће него у развијеним земљама ЕУ, где је просек 1,5\%. Учешће прехрамбене индустрије у привреди Србије је 4,5\%, а у земљама централне и источне Европе чланицама ЕУ је 2,7\%, док је у развијеним земљама ЕУ 1,9\% БДП.15 Због чињенице да се ове поменуте земље више ослањају на производе и услуге веће додате вредности у односу на Србију, а за време ове кризе тражња оваквих производа и услуга је снажно опала, долазимо до закључка да ће Србија имати осетно мањи пад производње када се пореди са земљама чланицама ЕУ.

\section{Спољнотрговинска размена}

Неспорно је да су земље ЕУ (пре свега Немачка и Италија) годинама биле најважнији спољнотрговински и економски партнери Србије. Поред прилива страних директних инвестиција, кредита, дознака (и донација), који претежно

13 European Commission, European economic forecast (spring 2020), Institutional Paper 125, May 2020.

14 The World Bank, 2020.

15 „Ефекат здравствене кризе на фискална и економска кретања у 2020. и препоруке за фискалну политику у 2021. години“, Република Србија, Фискални савет, 20. јул 2020. 
долазе из поменуте две земље, Европска унија је кључни стратешки партнер Србије због великог глобалног политичког, економског и технолошког значаја. Због свега наведеног тренутна, као и будућа економска кретања у ЕУ значајно утичу на кретања у Србији. Релативно спор опоравак привреда земаља Европске уније након пандемије ковида 19 одразиће се на успоравање раста увозне тражње и инвестирања, што ће се одразити и на успоравање раста домаћег извоза. Будући да српска економија у великој мери зависи од производње и трговине са ЕУ, инвестирања у српској производњи и трговини обично се покрећу директним страним улагањима, пре свега из ЕУ.

Графикон 3: Спољнотрговинска робна размена Србије 16

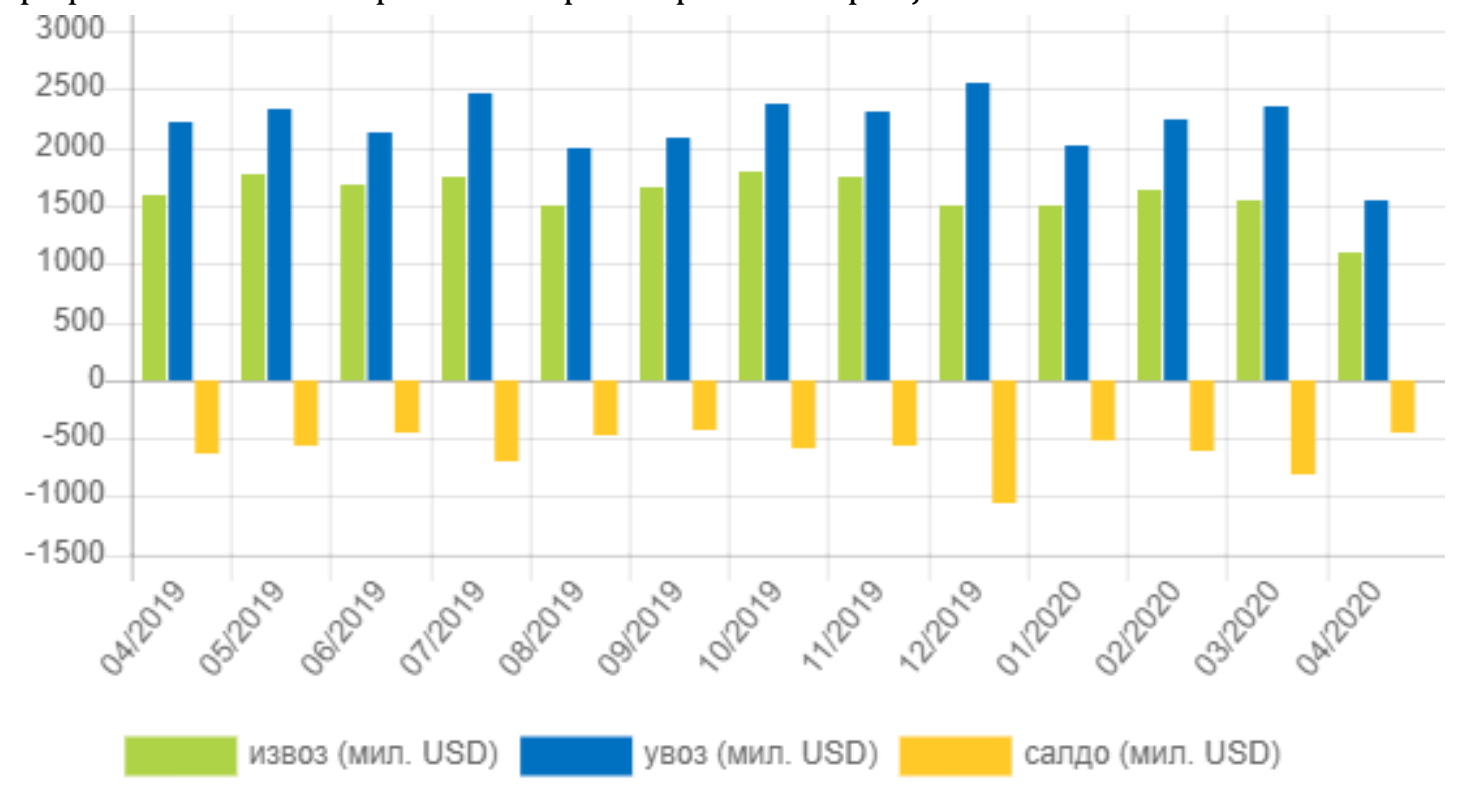

„Због релативно велике отворености трговине српска привреда ће бити снажно погођена контракцијом спољне тражње изазване ковид 19 кризом, посебно од главних трговинских партнера у Европској унији, што ће довести до пројектованог пада извоза за 8,5\%. Очекује се да ће негативни шок домаће потражње довести до снажнијег пада увоза за 9,5\%, а самим тим и до позитивног доприноса нето извоза расту БДП-а у 2020. години. Очекује се да ће се извоз и увоз према европској економској прогнози из пролећа 2020. године снажно опоравити у 2021. години. ${ }^{17}$

Укупна спољнотрговинска робна размена Републике Србије за период јануар-јун 2020. године износила је у доларима 20.426,2 милиона долара, што представља пад од 9,9\% у односу на исти период претходне године; док посматрано у еврима $18.543,4$ милиона евра, што је пад од 7,7\% у односу на исти период претходне године. У посматраном временском периоду извезено је робе у вредности од $8.621,0$ милиона долара, што чини пад од 11,1\% у односу на исти период претходне године, а увезено је робе у вредности од 11.805,2 милиона долара, што

\footnotetext{
16 Републички завод за статистику, https://www.stat.gov.rs/, 19/08/2020.

${ }^{17}$ European Commission, European economic forecast (spring 2020), op. cit.
} 
је за 9,1\% мање него у истом периоду претходне године. Извоз робе, изражен у еврима, имао је вредност од 7.822,4 милиона, што је пад од 8,9\% у поређењу са истим периодом претходне године. Увоз робе имао је вредност од 10.721,0 милиона, што представља пад од 6,8\% у односу на исти период прошле године. Дефицит износи $3.184,2$ милиона долара, што чини смањење од $3,1 \%$ у односу на исти период претходне године. Изражен у еврима, дефицит износи 2.898,5 милиона, што је смањење од $0,5 \%$ у поређењу са истим периодом претходне године. Покривеност увоза извозом је $73,0 \%$ и мања је од покривености у истом периоду претходне године, када је износила $74,7 \%{ }^{18}$

Спољнотрговинска робна размена била је највећа са земљама са којима Србија има потписане споразуме о слободној трговини, од чега земље чланице Европске уније чине 60,4\% укупне размене Србије. Други по важности партнер Републике Србије су земље ЦЕФТА, са којима наша земља остварује суфицит у размени од 961,3 милиона долара, који је углавном резултат извоза: пољопривредних производа (житарице и производи од њих), електричних машина и апарата, нафте и нафтних деривата, друмских возила и производа од метала. Извоз Србије износи $1.395,3$, а увоз 434,0 милиона долара за посматрани период. Покривеност увоза извозом је $321,5 \%$. Изражено у еврима, извоз износи $1.266,9$, а увоз 394,5 милиона евра (суфицит је 872,4 мил. евра, а покривеност увоза извозом 321,1\%). ${ }^{19}$ Према томе можемо закључити да ће смањење укупног извоза роба и услуга у 2020. години бити вођено прерађивачком индустријом услед пада екстерне тражње и поремећаја у глобалним ланцима вредности. Извоз Србије највише се ослања на тражњу ЕУ и региона. У 2019. години $2 / 3$ извоза пласирано је на тржиште ЕУ, затим на тржиште ЦЕФТА и тржишта земаља евроазијске уније. 20 Очекује се да ће у Републици Србији пад увоза бити већи од пада извоза, а опоравак увоза спорији услед комбинованог ефекта ниже домаће тражње и цена енергената. Највеће смањење вредности увоза очекује се код енергије и других индустријских инпута, услед пада цене енергената и смањења укупне економске активности, као и код увоза услуга. Са Кином имамо изузетно добру политичку и економску сарадњу, која се посебно развија у оквиру иницијативе $17+1$ као део пројекта Појас и пут. ${ }^{21}$

18 „Спољнотрговинска робна размена за текући период и јун 2020“, Републички завод за статистику, 31. јул 2020, https://www.stat.gov.rs/sr-latn/vesti/20200731spoljnotrgovinska-robna-razmena-za-tekuci-period-i-jun-2020/?a=0\&s=0, 19/08/2020.

19 Ibidem.

20 Погледати: Ана Јовић-Лазић и Ивона Лађевац, „Блиско иностранство у интеграционим иницијативама Руске Федерације: случај Евроазијске економске уније“, У: Душан Пророковић, Ана Јовић-Лазић (урс), Интеграциони прощеси у Евроазији, Институт за међународну политику и привреду, Београд, 2019, стр. 253-285.

21 Погледати: Ivona Lađevac, Branislav Đorđević, Ana Jović-Lazić, “Serbian Views on "16+1" and "Belt and Road" Initiative in China-EU relations", In: Liu Zuokui and Ivona Ladjevac (eds), The Cooperation between China and Balkan Countries under the "Belt and Road" Initiative, The Institute of European Studies (IES) at the Chinese Academy of Social Sciences, Beijing, China, 2019, pp. 54-70. 


\section{Остали економски показатељи}

Трајно присутне опасности у Републици Србији из домена економских показатеља су два кључна макроекономска дефицита: дефицит буџета и дефицит текућег рачуна. Поред тога, српска индустрија оптерећена је низом структурних слабости, који доводе до тога да индустријска структура не може да одговори глобалним захтевима савременог тржишта. ${ }^{22}$

Према оцени Народне банке Србије, инфлација би 2020. године требало да буде око доње границе дозвољеног одступања од циља $(3 \pm 1,5 \%)$ у условима ниже агрегатне тражње, као и нижих увозних цена, укључујући цену нафте. Средњорочно се очекује постепено приближавање инфлације централној вредности циља, чему би требало да допринесе опоравак потражње, подстакнут мерама монетарне и фискалне политике. ${ }^{23}$

Графикон 4: Стопа запослености $(15+\text { год })^{24}$

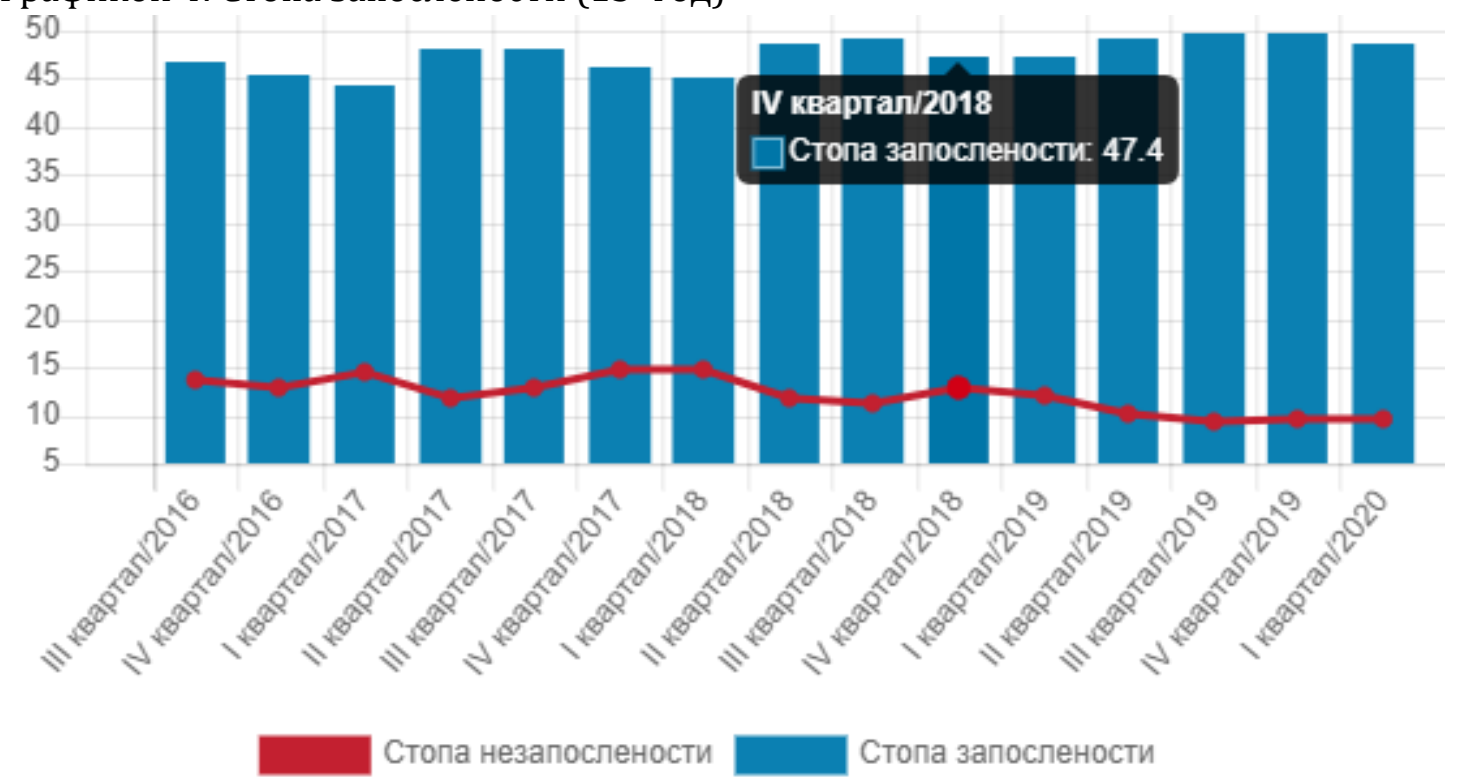

Због успоравања привредних активности постала су угрожена и радна места, као и приходи које породицама доносе плате запослених. Посебно су погођена сиромашна и рањива домаћинства, они који раде без уговора, са повременим уговорима, са уговорима на одређено време, као и самозапослени. Према званичним информацијама, 15.000 људи у Србији остало је без посла, али према истраживању које је спровела група за развојну иницијативу SeConS, око 200.000

${ }^{22}$ Sanja Jelisavac Trošić, „Serbia’s Sustainable Development Strategy and Industrial Policy for the European Union and the World Trade Organization“, in: M Yülek (ed.), Industrial Policy and Sustainable Growth, Springer, Singapore, 2018, p. 275. https://doi.org/10.1007/978-981-105741-0_23, p. 275.

23 Народна банка Србије, Макроекономска кретања у Србији, јун 2020.

${ }^{24}$ Републички завод за статистику, https://www.stat.gov.rs/, 20/08/2020. 
људи је изгубило посао у Србији, што одговара око 8\% запослених у фебруару 2020. године, укључујући неформалне и самозапослене раднике. ${ }^{25}$

Током ванредног стања на снази су између осталог били 12-сатни дневни полицијски час, обуставе транспорта и затварање свих неесенцијалних продавница, ресторана и кафића. Многа приватна предузећа у Србији због затварања нису могла да зараде за плате запослених, па се постављало питање њиховог опстанка. Посебно су погођене филијале, као и услужна предузећа, која су погођена више него продајне компаније.

Према истраживању индустријске производње по месецима Републичког завода за статистику, у поређењу са фебруаром 2020. године (100\%), индустријска производња износила је 79,33\% у марту, 70,37\% у априлу и $83,85 \%$ у мају. Проценат компанија које су након обуставе или смањења својих активности наставиле да послују у априлу је био 86,13 , а у мају је тај проценат порастао на 94,54, што показује добру брзину у повратку на нормалан ниво активности и пружа наду да ће се и запосленост повећати.

Графикон 5: Десезонирани индекси индустријске производње, 2019=10026

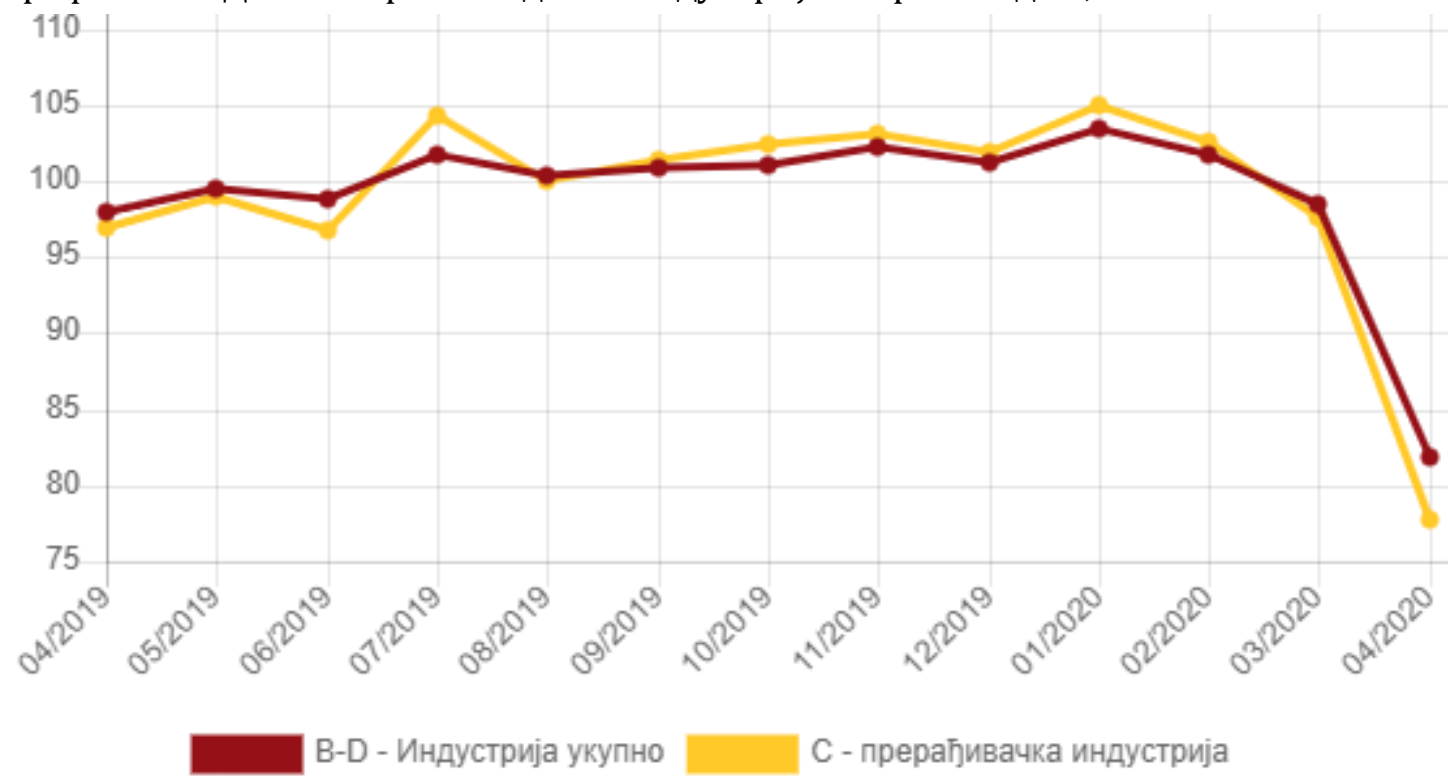

Извор: Републички завод за статистику, https://www.stat.gov.rs/

25 Изјава министра рада Зорана Ђорђевића на конференцији за новинаре после седнице Социјално економског савета 22. маја 2020 према: „Коначне цифре: У Србији 15.000 људи остало без посла“, Телеграф, 22. мај 2020, https://biznis.telegraf.rs/infobiz/3192976-konacne-cifre-u-srbiji-15000-ljudi-ostalo-bez-posla, 20/08/2020;

„Истраживање о ефектима пандемије и ванредног стања на запосленост, услове рада и бригу о домаћинству“, SeConS Група за развојну инищијативу, 13. мај 2020,

https://www.secons.net/article.php?a=131\&lng=Serbian, 20/08/2020.

26 Републички завод за статистику, https://www.stat.gov.rs/, 20/08/2020. 
Индустријска производња у периоду јануар-јун 2020. године, у поређењу са истим периодом 2019. године, мања је за 1,8\%. Посматрано по секторима, у јуну 2020. године, у односу на исти месец 2019, забележена су следећа кретања:

- сектор Прерађивачка индустрија - раст од 4,1\%,

- сектор Рударство - пад од 0,2\%, и

- сектор снабдевање електричном енергијом, гасом, паром и климатизација - пад од 4,5\%.27

Увођењем мера у циљу заштите здравља и смањивањем људских активности и радикалним променама понашања потрошача, поједине привредне гране су доживеле снажан пад у промету. У првом таласу борбе са вирусом посебно погођени сектори су били транспорт и туризам због ограничавања кретања људи. У Србији међу погођеним предузећима нашли су се и ХБИС, Фијат, Ер Србија и друга.

Поправљање фискалног резултата у претходне четири године у Србији урађено је успешним спровођењем фискалне консолидације на страни расхода, као и растом прихода услед бржег раста БДП-а и боље наплате пореза. У 2020. забележен је фискални дефицит услед смањених прихода и повећаних расхода, пре свега за медицинску опрему услед пандемије. Министарство финансија је проценило за 2020. годину фискални дефицит од 9\% БДП-а, са проценом пада БДП-а услед смањивања привредних активности од око 2\%. Расходи су наставили да расту и у другом кварталу услед имплементације мера подршке привреди. Програм мера Владе Републике Србије за ублажавање негативних ефеката вируса утицаће на раст дефицита буџета у 2020, као и на раст јавног дуга, али ће према проценама јавни дуг остати испод нивоа Мастришког критеријума од 60\% БДП-а. У том циљу у мају су емитоване седмогодишње еврообвезнице у износу од 2 милијарде евра, по каматној стопи од 3,375\% (купонска стопа 3,125\%). У јуну је референтна каматна стопа смањена на ниво од 1,25\%.28

Република Србија тренутно има довољно новца, девизних резерви и резерви злата и ову кризу још увек може да поднесе. Током прве половине 2020. године курс динара је био стабилан, инфлација је под контролом, а укупне девизне резерве износе 13,11 милијарди евра. Када се од укупних девизних резерви одбију средства пословних банака, која држе по основу обавезне резерве, нето девизне резерве су у марту 2020. износиле 10,94 милијарде евра. Стабилност монетарног сектора ће и убудуће зависити од тренутно непредвидљивог ширења или нестајања вируса ковида 19, као и начина на који ће се водити монетарна политика Републике Србије. ${ }^{29}$

27 „Индекси индустријске производње, јун 2020“, Републички завод за статистику, 31. јул 2020, https://www.stat.gov.rs/sr-latn/vesti/20200731-indeksi-industrijske-proizvodnje-jun2020/, 20/08/2020.

28 „Макроекономска кретања у Србији“, НБС, јун 2020, стр. 15.

29 Милош Обрадовић, „Економске последице COVID-19“, Нова економија, мај 2020, https://novaekonomija.rs/arhiva-izdanja/broj-70-maj-2020/ekonomske-posledice-covid-19 21/08/2020. 


\section{ЕКОНОМСКЕ МЕРЕ ПОДРШКЕ ПРИВРЕДИ СРБИЈЕ}

Сада је већ јасно да ће економске последице пандемије ковида 19 бити заиста велике. Очекују се велики падови у појединачним индустријама, падови у БДП држава, као и значајна економска назадовања на глобалном нивоу. Управо због тога појединачне државе улажу значајне напоре да се ублаже последице ковида 19 на домаћу привреду. Владе држава и централне банке широм света излазе са различитим пакетима мера. Међу државама које су направиле пакете различитих мера налази се и Република Србија. Мере су урађене у циљу очувања привредног развоја и функционисања привреде, као и у циљу смањења негативних последица ковида 19. Ванредно стање на територији Републике Србије проглашено је 15. марта 2020. године. ${ }^{30}$, а укинуто је 6. маја 2020. године. ${ }^{31} \mathrm{C}$ обзиром на то да пандемија још увек траје и није могуће до краја сагледати економске последице, највероватније ће бити и додатних државних мера помоћи привреди и очувању запослености. Тренутно се врши истраживање који су сектори најпогођенији, какви су изазови за предузећа и какви су им пословни планови, да би се у складу са могућностима могао осмислити нови сет мера помоћи привреди. ${ }^{32}$

Програм економских мера за подршку привреди Србије и смањивање негативних ефеката проузрокованих пандемијом вируса ковид 19 вредан је 5,2 милијарде евра. Можемо оценити да је добра комуникација која је остварена између привреде и Владе Републике Србије, уз праћење промена на терену, довела до усклађивања економских мера Владе са стварним потребама привреде за превазилажење шокова које је донела са једне стране пандемија, а са друге стране ванредне мере у циљу очувања здравља. Предвиђене мере обухватају фискалне погодности, пореске мере, финансијску подршку и директна давања. Први сет економских мера Владе Републике Србије за подршку привреди су регулисане са следећим Уредбама33:

Уредба о фискалним погодностима и директним давањима привредним субјектима у приватном сектору и новчаној помоћи грађанима у циљу ублажавања економских последица насталих услед болести ковид 19.34

Уредба о примени рокова у управним поступцима за време трајања ванредног стања. ${ }^{35}$

30 „Одлука о проглашењу ванредног стања (2020)“, Службени гласник РC, бр. 29/2020-3, Београд, 15. марта 2020.

31 „Одлука о укидању ванредног стања (2020)“, Службени гласник РС, бр. 65/2020-4, Београд, 6. мај 2020.

32 „Припрема се нови пакет мера за помоћ привредницима“, Радио телевизија Војводине, 16. јул 2020, https://rtv.rs/sr_lat/ekonomija/priprema-se-novi-paket-mera-za-pomocprivrednicima_1145268.html, 21/08/2020.

33 Шири сет уредби, правилника, измена закона и одлука, који ће бити освежаван са сваким новим документом, може се наћи на следећој адреси Министарства финансија Републике Србије: https://www.mfin.gov.rs/aktivnosti/ekonomske-mere-za-pomocprivredi-i-gradjanima/ 21/08/2020.

34 „Уредба о фискалним погодностима и директним давањима привредним субјектима у приватном сектору и новчаној помоћи грађанима у циљу ублажавања економских последица насталих услед болести COVID-19 (2020)“ Службени гласник PC, бр. 54/2020 и бр. 60/2020, Београд, 10. април 2020 и 24. април 2020. 
Уредба о пореским мерама за време ванредног стања ради ублажавања економских последица насталих услед болести ковид 19 изазване вирусом SARS-CoV-2.36

Уредба о утврђивању Програма финансијске подршке привредним субјектима за одржавање ликвидности и обртна средства у отежаним условима услед епидемије ковида 19, изазване SARS-CoV-237

Програм економских мера за подршку привреди је представљен 31. марта 2020. године. ${ }^{38}$ Програм економских мера је осмишљен имајући у виду две групе циљева: прва група циљева обухвата помоћ српској привреди, пре свега приватном сектору, да задржи ликвидност за време ванредног стања, а друга група циљева обухвата помоћ запосленима да задрже радна места и плате. Овај сет мера је осмишљен у моменту када се веровало да ће криза потрајати неколико месеци, а да ће се већ у трећем или четвртом кварталу привреда почети сама опорављати. С обзиром на то да се пандемија није смирила, за очекивати је да ће се доносити и додатне мере.

Програм економских мера за смањивање негативних ефеката проузрокованих пандемијом вируса ковид 19 и подршка привреди Србије садржи: 1) мере пореске политике, 2) директну помоћ приватном сектору, 3) мере за очување ликвидности и 4) остале мере. Мере пореске политике обухватају: а) одлагање плаћања пореза на зараде и доприносе за приватни сектор током трајања ванредног стања, уз каснију отплату настале обавезе у ратама са почетком најраније од 2021; б) одлагање плаћања аконтација пореза на добит у другом кварталу и в) ослобађање давалаца донација од обавезе плаћања ПДВ-а. Директна помоћ приватном сектору обухвата: а) директну помоћ предузетницима, микро, малим и средњим предузећима у приватном сектору у виду уплате помоћи у висини минималца за време трајања ванредног стања (3 минималне зараде) и б) директну помоћ великим предузећима у приватном сектору у виду уплате помоћи у висини 50\% нето минималне зараде за време трајања ванредног стања), за запослене којима је решењем утврђен престанак рада (члан 116 и 117. Закона о раду). Под мере за очување ликвидности спадају: а) програм финансијске

35 „Уредба о примени рокова у управним поступцима за време трајања ванредног стања (2020)“ Службени гласник РC, бр. 41/2020 и бр. 43/2020, Београд, 24. март 2020 и 27. март 2020.

36 „Уредба о пореским мерама за време ванредног стања ради ублажавања економских последица насталих услед болести COVID-19 изазване вирусом SARS-CoV-2 (2020)“ Службени гласник РС, бр. 38/2020, Београд, 20. март 2020.

37 „Уредба о утврђивању Програма финансијске подршке привредним субјектима за одржавање ликвидности и обртна средства у отежаним условима услед епидемије Цовид-19 изазване SARS-CoV-2 (2020)“ Службени гласник PC, бр. 54/2020, Београд, 11. април 2020.

38 „Министар Синиша Мали представио Програм економских мера за подршку привреди“, Министарство финансија Републике Србије, 31. март 2020,

https://www.mfin.gov.rs/aktivnosti/ministar-finansija-predstavio-program-ekonomskihmera-za-podrsku-privredi-srbije-i-smanjivanje-negativnih-efekata-prouzrokovanihpandemijom-virusa-kovid-19/,23/07/2020. 
подршке привреди у условима ковида 19 кризе Фонда за развој Републике Србије и б) гарантна шема за подршку привреди у условима ковида 19. У остале мере спадају: а) мораторијум на исплату дивиденди до краја године, осим за ЈП и б) фискални стимуланс - директна помоћ свим пунолетним грађанима. 39

Са одлагањем плаћања пореза и доприноса на зараде и са исплатом минималне зараде, део радних места и пословања је сачуван, што је поред очувања стабилности привреде и за очување социјалног мира веома битно. Мере државе усмерене на очување запослености у условима пандемије ковида 19 за сада дају добре резултате. Најспорнија мера предложеног програма је исплата по 100 евра свим пунолетним грађанима Србије, у циљу подстицања тражње након завршетка ванредног стања.

\section{ОЦЕНЕ ЕКОНОМСКИХ МЕРА И ПРОГНОЗЕ ТРЕНДОВА У ПРИВРЕДИ СРБИЈЕ}

Јасно је да је пандемија ковида 19 направила веома озбиљне проблеме привреди Србије и да је за очување привредног система била неопходна интервенција државе. Може се рећи да постоји сагласност свих привредних, стручних и политичких фактора око те чињенице. Другачија мишљења се јављају само око избора конкретних мера и њихове ефикасности да остваре постављене циљеве.

Фискални савет је ту да процени кредибилност фискалне политике са аспекта поштовања утврђених фискалних правила и да осигура јавност и одговорност у вођењу фискалне политике земље. ${ }^{40}$ Фискални савет Републике Србије у оцени мера Владе потврдио је да су мере оправдане, посебно у циљу помоћи што већем делу приватног сектора да опстане, чиме се чувају радна места, смањује штета за грађане, привреду и последично и јавне финансије. Мере ће коштати пореске обвезнике преко 3 милијарде евра, од чега 2,5 милијарде евра за одлагање пореских обавеза, буџетску помоћ за исплату зарада и за повећање ликвидности и ове мере Савет оцењује позитивно, јер би трошак без оваквих мера био далеко већи. Међутим, исплата 100 евра свим пунолетним грађанима Србије извлачи из буџета 600 милиона евра и оцењена је вишеструко негативно. Мера је оцењена економски неефикасном, социјално нефокусираном и фискално неодговорном. За финансирање свих буџетских обавеза заједно са овим мерама Владе током 2020.

39 „Програм економских мера за смањивање негативних ефеката проузрокованих пандемијом вируса ковид 19 и подршку привреди Србије“, Министарство финансија Републике Србије, 31. март 2020, https://www.mfin.gov.rs/aktivnosti/ministar-finansijapredstavio-program-ekonomskih-mera-za-podrsku-privredi-srbije-i-smanjivanje-negativnihefekata-prouzrokovanih-pandemijom-virusa-kovid-19/, 23/08//2020, стр 1-4.

40 Sanja Jelisavac Trošić, Stojanović-Višić Biljana, "EU Budget and Budget of Serbia: Impact on Serbia's Accession to the EU", Ekonomika preduzeća (Journal of Business Economics and Management), Vol. LXVI, No. 2, 2018, p. 274. 
године Република Србија мора да обезбеди око 6,5 милијарди евра од кредитора, што је оцењено као велики изазов. ${ }^{41}$

Због кризе, као и због мера, учешће јавног дуга у БДП-у ће се повећати за преко 10 процентних поена, што доводи до учешће јавног дуга од преко 60\% БДП-а. Ово је неодрживо висок дуг за Србију и мораће се смањивати наредних година испод 50\%. Оцена Фискалног савета је да јавне финансије Србије имају капацитет да се изборе са текућом кризом без макроекономских нестабилности уколико се води одговорна фискална политика. ${ }^{42}$

Иако се у први мах процењивало да ће се здравствена криза изазвана вирусом зауставити током лета (а други талас да ће бити током јесени), то се није десило, па су се поставили нови изазови пред привреду и Владу Републике Србије. У међувремену дошло је до раста неравнотежа у буџету, раста јавног дуга, пада производње и промета у привреди и још много других негативних кретања.

Народна банка Србије одлучила је у јуну да настави са ублажавањем монетарне политике и референтну каматну стопу је снизила за 25 базних поена, на ниво од 1,25\%. Инфлаторни притисци у Србији за сада остају ниски услед ниске агрегатне тражње и цене нафте.

Фискални савет, уз ограду због високог степена неизвесности за будуће ефекте пандемије, тренутни привредни пад процењује на око $3 \%$, што ће довести до смањења броја запослених за 30-50 хиљада. Пад БДП-а због структуре домаће привреде биће мањи од већине европских земаља, док се фискални дефицит процењује на око 7\% БДП-а, што је преко 3 милијарде евра, уколико не буде новог пакета помоћи привреди. Оцена је да би нови пакет помоћи привреди морао бити далеко мањи од првог, селективан и привремен. ${ }^{43}$

Препоруке Фискалног савета за 2021. годину су: одржавати фискални дефицит од око $2 \%$, јер би се тим дефицитом зауставио раст јавног дуга; остваривати прилагођавање буџета, првенствено контролом плата и пензија у јавном сектору, а никако смањењем јавних финансија; замрзавање плата у јавном сектору; умерено повећање пензија искључиво надоградњом „швајцарске“ формуле, а никако одлуком Владе; повећавање улагања државе у инфраструктуру, са средствима од смањења улагања у безбедносни сектор; опремање здравства. ${ }^{44}$

41 „Оцена антикризног програма економских мера (2020)“, Фискални савет Републике Србије, 8. април 2020, Београд; http://www.fiskalnisavet.rs/doc/ocene-imisljenja/2020/FS-Ocena_antikriznog_programa_ekonomskih_mera.pdf, 25/08/2020, стр. 3.

42 Ibidem, cтр. 4-5.

43 „Ефекат здравствене кризе на фискална и економска кретања у 2020. и препоруке за фискалну политику у 2021. години (2020)“, Фискални савет Републике Србије, 20. јул 2020, Београд, http://www.fiskalnisavet.rs/doc/analize-stavovipredlozi/2020/FS_Efekat_zdravstvene_krize_na_fiskalna_i_ekonomska_kretanja_u_2020_+pre poruke_za_2021.pdf, 25/08/2020.

${ }^{44}$ Ibidem. 
Табела 1: Преглед економских кретања у Србији 2018-2021

\begin{tabular}{|c|c|c|c|c|}
\hline & 2018. & 2019. & 2020. & 2021. \\
\hline $\begin{array}{l}\text { Реални БДП, мг. } \\
\text { стопе раста (у } \\
\%)\end{array}$ & 4,4 & 4,2 & $-1,5$ & 6,0 \\
\hline $\begin{array}{l}\text { Приватна } \\
\text { потрошња (y \%) }\end{array}$ & 3,1 & 3,2 & $-1,9$ & 5,1 \\
\hline $\begin{array}{l}\text { Приватне } \\
\text { инвестиције }(\mathrm{y} \\
\%)\end{array}$ & 13,6 & 13,4 & $-5,2$ & 10,7 \\
\hline $\begin{array}{l}\text { Државна } \\
\text { потрошња (y \%) }\end{array}$ & 3,7 & 3,0 & 2,4 & 2,0 \\
\hline $\begin{array}{l}\text { Државне } \\
\text { инвестиције (у } \\
\%)\end{array}$ & 43,1 & 30,4 & $-17,0$ & 26,6 \\
\hline Извоз (у \%) & 8,3 & 8,5 & $-1,9$ & 13,2 \\
\hline Увоз (у \%) & 11,6 & 9,5 & $-4,41$ & 3,2 \\
\hline $\begin{array}{l}\text { Стопа } \\
\text { незапослености } \\
(\text { (у \%) } \\
\end{array}$ & 12,7 & 10,4 & 9,7 & - \\
\hline $\begin{array}{l}\text { Номиналне } \\
\text { зараде }(y \text { \%) }\end{array}$ & 6,5 & 10,6 & 10,3 & - \\
\hline $\begin{array}{l}\text { Новчана маса } \\
\text { (M3) (y \%) }\end{array}$ & 14,5 & 8,4 & - & - \\
\hline $\begin{array}{l}\text { Индекс } \\
\text { потрошачких } \\
\text { ценаг (у \%) }\end{array}$ & 2,0 & 1,9 & 1,5 & 1,8 \\
\hline $\begin{array}{l}\text { НБС референтна } \\
\text { каматна стопад } \\
(\mathrm{y} \%)\end{array}$ & 3,0 & 2,25 & 1,25 & - \\
\hline $\begin{array}{l}\text { Дефицит текућег } \\
\text { рачуна ВРМ-6 (у } \\
\text { \% БДП-а) }\end{array}$ & 4,8 & 6,9 & 5,0 & 5,5 \\
\hline
\end{tabular}

а Не укључује ефекат промена у залихама.

б Анкета о радној снази. Ревидирани подаци од 2014. године према новој методологији АРС. Податак за Т1 2020.5.

в Номиналне зараде се од 2017. објављују према новој методологији. Податак за Т1 2020.

г Подаци о инфлацији се односе на мг. инфлацију у децембру: (Pt/Pt-12)*100-100.

д Последњи расположив податак.

Извор: „Макроекономска кретања у Србији“, НБС, јун 2020, стр. 29.

Монетарна политика Србије је до сада била успешна, док је динар још увек стабилан, а Србија за сада има добре девизне резерве. Макроекономска стабилност постоји и постоји маневарски простор. Очекивано успоравање прилива капитала из иностранства ће извршити притисак на стабилност курса динара. У средњорочном периоду може се очекивати и притисак на девизне резерве Србије. Због смањивања нивоа страних директних инвестиција, смањених 
дознака из иностранства, смањеног броја радника који раде у иностранству доћи ће до притиска на курс динара и уколико се интервенише са резервама Народне банке Србије, оне ће се наравно трошити.

Направити добру пројекцију привредних кретања немогуће је у овом тренутку. Треба напоменути да ће будућа привредна кретања у Србији и у свету у великој мери зависити и од очекивања инвеститора и очекивања потрошача. Владају велике недоумице, као на пример: да ли ће се улагати у мала и средња предузећа, да ли ће се спашавати крупни капитал и банке и слично. Немогућност слободног кретања запослених, капитала, производа и услуга довело је до кидања логистичких ланаца снабдевања. Пред гашењем су читаве индустрије, док се послови затварају, успоравају се и стају инвестирања, а потрошња је такође успорена због разних фактора. Уколико се наставе ови трендови, долазиће све више и до успоравања и гашења производње која неће моћи да прода своје производе. Тиме се успорава цео економски ток и обрт - инвестирање, производња, потрошња - влада неизвесност код свих актера и очекивања ка покретању токова и побољшању постају све више песимистична. Сви актери постају опрезнији и долази до општег економског успоравања.

Чак и у оваквој ситуацији биће добитника, посебно у секторима који су отпорни на пандемију. Уколико велика и снажна предузећа искористе јефтине кредитне линије које тренутно гарантују државе у свету, оне могу искористити кризу да куповином ослабљених мањих предузећа униште конкуренцију и остваре монопол на тржишту. У оваквом сценарију је сасвим могуће да богати постану још богатији, а да сиромашни пропадну. Овде можда и најважнију улогу могу имати државе. Развијене земље су већ започеле посао, па током кризе изазване вирусом не дозвољавају преузимања стратешки важних компанија у њиховим државама од стране предузећа страних држава. Све је очигледније да државне интервенције у привреди постају све снажније и не заустављају се само на пакетима помоћи. Видеће се колико ће остале државе бити спремне на својим тржиштима да спрече монополско понашање. Иако је међународна сарадња по природи неопходна током глобалног шока попут пандемије, државе у свету данас све више нису вољне да сарађују у глобалним питањима. 45 У међувремену се најављују и још радикалније мере државног интервенционизма, који све више подрива постулате слободног тржишта. Свеукупно посматрано, цео свет ове 2020. године ће претрпети губитке, док ће се сиромаштво у свету повећати.

Пад светске привреде током 2020. године је незапамћен од Другог светског рата. Када се погледа свет у целини, виде се најаве централних банака да ће оне интервенисати колико год то буде потребно. ${ }^{46}$ Монетарне мере све више се

45 Alicia García Herrero, „The Pandemic Requires a Coordinated Global Economic Response“, Intereconomics, Vol. 55, No. 2, 2020, p. 66.

46 Погледати: Rajiv Chowdhury, Shammi Luhar, Nusrat Khan, Sohel Reza Choudhury, Imran Matin, Oscar H. Franco, „Long-term strategies to control COVID-19 in low and middle-income countries: an options overview of community-based, non-pharmacological interventions", 
прилагођавају насталој ситуацији; државе се све више задужују ради интервенција на сопственом тржишту. 47 Обим мера у свету је незабележен од санирања последица Другог светског рата до данас. ${ }^{48}$ Назире се да ће ова година бити прекретница и да ће највероватније будућност осликати нека нова економска реалност.

Република Србија има шансу да започне са отклањањем слабости не ослањајући се на друге и да пронађе свој сопствени концепт одрживог развоја. Мала је вероватноћа да ће се поновити ограничења која су била на снази током ванредног стања, а и за привреду је боља опција да се, уколико за то постоји здравствена потреба, дужи период трају умерена ограничена у пословању. Нови сет мера подршке привреди је могуће извести из примарне емисије. Нове мере би требало да буду више селективне. Тешко ће бити донети одлуке. Уколико не буде нових мера подршке, прогнозирани пад од $3 \%$ ће бити знатно већи.

Осим мера које се очекују од државе, привредници би морали мењати модел пословања, можда и грану пословања. Кризна времена увек захтевају тешке одлуке и прилагођавања. Сада је много више него раније потребно стратешки размишљати и планирати.

Привредници у Србији предлажу да се у другом кругу помоћи још три месеца настави са исплатом минималне зараде за раднике и да мировање отплате кредита остане на снази, али само за најугроженије секторе. Све више је стручњака и привредника који предвиђају да неће бити скорог опоравка привреде и да ће криза потрајати. Најоптималније је, али не и реално, да нови пакет мера буде на нивоу претходног. Пошто се са сваким даном трајања претње од вируса ковид 19 повећавају трошкови и привреде и државног система помоћи, неминовност је да ће скоро све државе света повећати јавни дуг. Такође се мора обратити посебна пажња на финансирање и организациони концепт здравственог система, јер они представљају највећи изазов за обезбеђивање

European journal of epidemiology, Vol. 35, No. 8, 2020, 743-748; Viral Acharya, Bjorn Imbierowicz, Sascha Steffen and Daniel Teichmann, „Does the lack of financial stability impair the transmission of monetary policy?“, Journal of Financial Economics, in press, available online 20 June 2020.

https://www.sciencedirect.com/science/article/abs/pii/S0304405X20301781\#: :text=Mon etary $\% 20$ policy $\% 20$ transmission $\% 20$ may $\% 20$ be,put $\% 20$ to $\% 20$ use $\% 20$ for $\% 20$ investment; Robert Kurtzman, David Zeke, „Misallocation costs of digging deeper into the central bank toolkit", Review of Economic Dynamics, Vol. 38, 2020, pp. 94-126

47 Погледати: Donato Masciandaro, „COVID-19 Helicopter Money, Monetary Policy and Central Bank Independence: Economics and Politics“, BAFFI CAREFIN Centre Research Paper, 2020 April (2020-137).; Agnès Bénassy-Quéré, Arnoud Boot, Antonio Fatás, Marcel Fratzscher, Clemens Fuest, Francesco Giavazzi, Ramon Marimon, Philippe Martin, Jean Pisani-Ferry, Lucrezia Reichlin, Dirk Schoenmaker, „A proposal for a Covid credit line“, VoxEU, 21 March 2020, https://voxeu.org/article/proposal-covid-credit-line, 29/08/2020.

48 Погледати: Bibow Jorg, „Pushing the limits: the European Central Bank's role in restoring sustainable growth“, ETUI Research Paper-Working Paper, 23 March 2020. 
бољих и ефикаснијих здравствених услуга које би имале универзални обухват популације у држави. ${ }^{49}$

Сада, у другом кругу требало би пружити подршку предузећима важним за одржање привредних активности појединих региона у држави, затим предузећима усмереним на извоз, као и компанијама које запошљавају већи број људи. Код планирања свих будућих мера морало би се поћи са две стране - шта нам је циљ и шта хоћемо да постигнемо, али и шта имамо, која су нам средства и капацитети.

Како се најављују нове државне мере за очување економског система, јасно је да ће оне морати бити усмереније, не толико широке и обимне, усмерене ка најугроженијим секторима и најугроженијим радницима. Сада је већ очигледно да ће криза да траје много дуже од неколико месеци. Дошло је до успоравања економске активности широм света, па и у нашој држави. Иако су мере државе усмерене на очување запослености у условима пандемије дале резултате, постаје јасно да ће држава и даље морати да интервенише на тржишту и да помогне привредним субјектима, као и запосленима, да у наредним продуженим месецима лошијих привредних активности због трајања пандемије очувају своје изворе прихода. Велики број држава света ће ове године да уђе у рецесију, а од за сада неизвесног момента окончања пандемије зависи да ли ће привредни системи упасти у депресију.

\section{ЗАКЉУЧАК}

Међу позитивним кретањима са којима је Србија дочекала ову ковид 19 кризу можемо издвојити стабилне макроекономске показатеље, добру фискалну политику, добру монетарну политику (уз упитну политику јаког динара), пореске реформе, смањење јавног дуга, релативно стабилан прилив страних директних инвестиција, побољшан кредитни рејтинг и друго. Због ових снажних основа у виду макроекономске стабилности, динамике раста и фискалног простора, као и за услове кризе повољне структуре привреде (релативно гледано велики део привреде Србије производи основна тзв. егзистенцијална добра, за којима у кризи тражња није значајно опала), јавила се и могућност да глобална рецесија на Србију има мање последице у односу на друге европске земље. Србија се у претходним годинама трансформисала у полако растућу економију са ниском инфлацијом, уравнотеженом фискалном позицијом, опадајућим јавним дугом, мањом екстерном неравнотежом и опоравком тржишта рада, што је нашој привреди помогло да за сада без већих привредних шокова одговори на текуће изазове.

49 Сања Јелисавац Трошић, Тодић Драгољуб, Стаменовић Милорад, Светска трговинска организација, животна средина и систем здравствене заштите, Институт за међународну политику и привреду. Београд, 2018, стр. 83. 
У условима свеопште светске кризе изазване пандемијом вируса ковид 19 несумњиво је да су мере државе биле потребне. Државним мерама се помогло и даље се помаже привреди Србије да се сачува у кризним месецима и да се подстакне опоравак. Без мера Владе Републике Србије последице по привреду вируса ковида 19 би биле много веће. Неопходно је да се Република Србија, уз посебну дозу опреза, прилагођава регионалним и глобалним кретањима на тржишту, која су свакако теже предвидива због последица пандемије.

Већина ефеката затварања и смањења највећег броја економских активности због ковида 19, као и економских мера за подршку привреди у Србији, биће јаснији и видљивији најраније крајем године. Промене изазване ковидом 19 највероватније ће касније укључивати измењене моделе пословања. Пандемија је покидала или скратила глобализоване ланце снабдевања. Производно позиционирање биће углавном ближе купцима у развијеним земљама, а то у нашем случају значи да би Србија због близине могла постати занимљивија за предузећа из ЕУ. Такође, Република Србија може постати занимљиво тржиште за инвестиције из Кине у производњу, која би тако била ближа тржишту ЕУ.

Пандемија ковида 19 не може се изједначити са скорашњим економским кризама. Код садашње кризе ни узрок ни решење није економско. Са сваким даном продужавања пандемије вируса постоји све већа шанса да неке земље неће спроводити праву политику или да ће притисак кризе бити превелик за њихов државни и економски систем, што би за последицу имало прерастање рецесије у депресију. Уколико криза, незадовољство и пандемија дуже потрају, могући су и јачи потреси светске привреде. Већ и пре ове пандемије стабилност и уређеност светског економског система су нарушавали протекционизам, трговински рат САД и Кине, скраћивање ланаца снабдевања, Брегзит, регионализација и друге појаве. Када се томе дода криза изазвана пандемијом, могуће је да ће се кроз неколико година дешавати и суштинска промена глобализованог света. Нарастајуће препреке у слободном протоку људи, производа и капитала могу све више постајати трајнија појава него што се на почетку кризе мислило.

Очекује се да криза изазвана ковидом 19 буде далеко већа од оне изазване глобалном финансијском кризом из 2008. године. За Србију, као и за све земље света, остаје проблем секундарних ефеката кризе изазване вирусом ковид 19, који би могли потрајати у дужем временском периоду. Велики проблем је што у међувремену расте број предузећа која неће моћи да обнове своје пословање, а самим тим отежава се целокупна економска стабилност. За сада је јасно да се светска и српска привреда реструктуира, више послова и трговине се обавља путем интернета, број пословних путовања је смањен и ствара се нека нова нормала.

\section{ЛИТЕРАТУРА}

- Acharya Viral, Imbierowicz Bjorn, Steffen Sascha and Teichmann Daniel, „Does the lack of financial stability impair the transmission of monetary policy?“, Journal of Financial Economics, 20 June 2020. 
- Bénassy-Quéré Agnès, Boot Arnoud, Fatás Antonio, Fratzscher Marcel, Fuest Clemens, Giavazzi Francesco, Marimon Ramon, Martin Philippe, Pisani-Ferry Jean, Reichlin Lucrezia, Schoenmaker Dirk, „A proposal for a Covid credit line“, VoxEU. org, 21 March 2020.

- European Commission, European economic forecast (spring 2020), Institutional Paper 125, May 2020.

- IMF, World Economic Outlook (April 2020).

- IMF, World Economic Outlook Update, June 2020: A Crisis Like No Other, An Uncertain Recovery, June 24, 2020.

- IMF, World Economic Outlook, April 2020: The Great Lockdown, April 6, 2020.

- Јелисавац Трошић Сања, Тодић Драгољуб, Стаменовић Милорад, Светска трговинска организација, животна средина и систем здравствене заштите, Институт за међународну политику и привреду, Београд, 2018, стр. 83.

- Jelisavac Trošić Sanja, „Serbia's Sustainable Development Strategy and Industrial Policy for the European Union and the World Trade Organization“, in: M Yülek (ed.), Industrial Policy and Sustainable Growth, Springer, Singapore, 2018, https://doi.org/10.1007/978-981-10-5741-0_23, p. 275.

- Jelisavac Trošić Sanja, Stojanović-Višić Biljana, „EU Budget and Budget of Serbia: Impact on Serbia's Accession to the EU“, Ekonomika preduzeća (Journal of Business Economics and Management), March-April 2018, year LXVI, Serbian Association of Economists (Savez ekonomista Srbije), DOI:10.5937/EKOPRE1804266J, p. 274.

- Jorg Bibow, „Pushing the limits: the European Central Bank's role in restoring sustainable growth“, ETUI Research Paper-Working Paper, 23 March 2020.

- Јовић-Лазић Ана, Лађевац Ивона, „Блиско иностранство у интеграционим иницијативама Руске Федерације: случај Евроазијске економске уније“, Интеграциони процеси у Евроазији, Душан Пророковић, Ана Јовић-Лазић (ур), Институт за међународну политику и привреду, Београд, 2019, стр. 253-285.

- Kurtzman Robert, Zeke David, „Misallocation costs of digging deeper into the central bank toolkit", Review of Economic Dynamics, 3. April 2020.

- Lađevac Ivona, Đorđević Branislav, Jović-Lazić Ana, „Serbian Views on 16+1 and Belt and Road Initiative in China-EU relations", The Cooperation between China and Balkan Countries under the "Belt and Road" Initiative, Liu Zuokui and Ivona Ladjevac (eds.), The Institute of European Studies (IES) at the Chinese Academy of Social Sciences, Beijing, China, 2019, pp. 54-70.

- Masciandaro Donato, „COVID-19 Helicopter Money, Monetary Policy and Central Bank Independence: Economics and Politics“, BAFFI CAREFIN Centre Research Paper, 2020 April (2020-137).

- Народна банка Србије, Макроекономска кретања у Србији, јун 2020.

- SeConS група за развојну инцијативу, „Istraživanje o efektima pandemije i vanrednog stanja na zaposlenost, uslove rada i brigu o domaćinstvu“, https://www.secons.net/article.php?a=131\&lng=Serbian. 
- Herrero Alicia García, „The Pandemic Requires a Coordinated Global Economic Response“, Intereconomics, 2020 Mar 1;55(2):66.

- Chowdhury Rajiv, Luhar Shammi, Khan Nusrat, Choudhury Sohel Reza, Matin Imran, Franco Oscar H., „Long-term strategies to control COVID-19 in low and middleincome countries: an options overview of community-based, non-pharmacological interventions", European journal of epidemiology, 2020 July 13:1-6.

- „Економске последице цОВИД-19“, https://novaekonomija.rs/arhiva-izdanja/broj70-maj-2020/ekonomske-posledice-covid-19.

- „Ефекат здравствене кризе на фискална и економска кретања у 2020. и препоруке за фискалну политику у 2021. години“, Република Србија, Фискални савет, 20. јул 2020.

- „Индекси индустријске производње, јун 2020“, https:/www.stat.gov.rs/srlatn/vesti/20200731-indeksi-industrijske-proizvodnje-jun-2020/?a=0\&s=0.

- „Изјава министра рада Зорана Ђорђевића на конференцији за новинаре после седнице Социјалноекономског савета 22. маја 2020“, https://biznis.telegraf.rs/info-biz/3192976-konacne-cifre-u-srbiji-15000-ljudiostalo-bez-posla

- „IMF Staff Completes a Virtual Review Mission to Serbia July 3, 2020“, Press Release No. 20/253,

- https://www.imf.org/en/News/Articles/2020/07/02/pr20253-serbia-imf-staffcompletes-a-virtual-review-mission

- „Квартални бруто домаћи производ у Републици Србији, први квартал 2020. године“, https://www.stat.gov.rs/sr-latn/vesti/20200601-kvartalni-bruto-domaciproizvod-u-republici-srbiji-prvi-kvartal-2020-godine/

- „ММФ: Економска ситуација гора него што се предвиђало“, https://www.slobodnaevropa.org/a/mmf-ekonomska-situacija-gora-odpredvidjanja/30690214.html.

- „Макроекономска кретања у Србији“, НБС, јун 2020, стр. 15.

- „Министар Синиша Мали представио Програм економских мера за подршку привреди“, Министарство финансија Републике Србије,

- https://www.mfin.gov.rs/aktivnosti/ministar-finansija-predstavio-programekonomskih-mera-za-podrsku-privredi-srbije-i-smanjivanje-negativnih-efekataprouzrokovanih-pandemijom-virusa-kovid-19/,23/07/2020.

- „Министарство финансија Републике Србије“,

- https://www.mfin.gov.rs/aktivnosti/ekonomske-mere-za-pomoc-privredi-igradjanima/

- „Оцена антикризног програма економских мера“, Република Србија, Фискални савет, 8. април 2020, стр. 3.

- „Припрема се нови пакет мера за помоћ привредницима“, РТВ, 16. јул 2020., https://rtv.rs/sr_lat/ekonomija/priprema-se-novi-paket-mera-za-pomocprivrednicima_11452 68.html 
- „Програм економских мера за смањивање негативних ефеката проузрокованих пандемијом вируса Ковид-19 и подршку привреди Србије“, Министарство финансија Републике Србије, стр 1-4.

- "Службени гласник РС“, бр. 38/2020, од 20. марта 2020.

- „Службени гласник РС“, бр. 41/2020 и 43/2020.

- „Спољнотрговинска робна размена за текући период и јун 2020“, https://www.stat.gov.rs/sr-latn/vesti/20200731-spoljnotrgovinska-robna-razmenaza-tekuci-period-i-jun-2020/?a=0\&s=0.

- „Србија једина земља којој ММФ није смањио прогнозу раста“, https://www.tvmost.info/post/srbija-jedina-zemlja-kojoj-mmf-nije-smanjioprognozu-rasta.

- „Службени гласник PC“, број 29, 15. марта 2020, 29/2020-3.

- „Службени гласник РС“, број 65/2020. 65/2020-4.

- „Службени гласник РС“, бр. 54/2020 и 60/2020, 11. април 2020.

- „Службени гласник РС“, бр. 54/2020, 11. априла 2020.

- „Serbia Overview, The World Bank”,

- https://www.worldbank.org/en/country/serbia/overview.

\title{
ECONOMIC CONCEQUENCES OF COVID-19 AND SUPPORT MEASURES TO THE ECONOMY OF REPUBLIC OF SERBIA
}

\begin{abstract}
The crisis caused by the COVID-19 virus brings unforeseeable economic consequences that threaten to be extremely devastating for the whole world. These paper considers several issues about economic consequences and measures to overcome chisis in Serbia. At the beginning of the analysis, the economic consequences of the COVID-19 virus on the world economy were considered, then the economic consequences of the virus on the economy of the Republic of Serbia were analyzed. In the paper then follows the Government of Serbia economic measures program aiming at reducing the negative effects in the Serbian economy caused by the pandemic, and assessment of the success of these measures, as well as forecasting future economic trends that await us in the coming period. Among the positive trends with which Serbia was caught by COVID-19 crisis, we can single out stable macroeconomic indicators, good fiscal and monetary policy, tax reforms, reduction of public debt, relatively stable inflow of foreign direct investments, improved credit rating. Due to strong bases in the form of macroeconomic stability, dynamic growth and fiscal space, as well as for the conditions of the crisis favorable structure of the economy, because a large part of the Serbian economy produces the basic existential goods, for which the demand did not fall significantly in the crisis,
\end{abstract}


there was a situation that the global recession has less negative consequences for Serbia in comparison with other European countries. Without the economic measures of the Government of the Republic of Serbia, the consequences for the economy of the COVID-19 virus would be more devastating. Unfortunately, if the crisis, growing dissatisfaction with the measures of distancing and COVID-19 pandemics last longer, stronger earthquakes of the world economy are possible. For now, it is clear that the world and Serbian economy are being restructured, more business and trade is being done via the Internet, the number of business trips has been reduced and a new norm of doing bussiness is being created. It is possible that a substantial change in the globalized world will take place in a few years. Growing obstacles to the free flow of people, products and capital may increasingly become a more permanent phenomenon than previously thought.

Key words: economy, economic consequences, COVID-19, Republic of Serbia 